prezentujące źródła historyczne wraz z narzędziami służącymi ich krytyce. Szkolną edukację historyczną wspomagać mogę te multimedia, które umożliwiają kontakt uczniów ze źródłami historycznymi, a więc Internet, e-podręczniki, gry komputerowe itp. Szczególną rolę w tym względzie pełnić powinny internetowe witryny bibliotek i muzeów. Takie zadanie stawiać należy także przed archiwami, z których większość czynnie uczestniczy w edukacji społeczeństwa, wykorzystując w tej materii technologie informatyczne. Nie ma więc żadnych wątpliwości, że przyszłość szeroko rozumianej nauki historycznej opierać się będzie w dużej mierze na multimediach.

Należy mieć nadzieję, że - zgodnie z zapowiedzią organizatorów w 2013 r. ukaże się publikacja, zawierająca teksty wszystkich omówionych wyżej wystąpień, uzupełniona także o te referaty, które z różnych względów nie zostały wygłoszone podczas konferencji ${ }^{46}$.

Hubert Mazur

Archiwum Państwowe w Kielcach

\title{
SPRAWOZDANIE Z OBCHODÓW JUBILEUSZU 90. ROCZNICY URODZIN PROFESORA ANDRZEJA TOMCZAKa
}

A ndrzej Tomczak urodził się 12 września
1922 roku we wsi Biesiekierz Górzewo,
obecnie powiat Zgierz. Jest synem Anieli z domu
Twardowskiej oraz ojca Józefa, a wnukiem Kazi-
mierza Twardowskiego - profesora Uniwersyte-
tu Jana Kazimierza we Lwowie, twórcy filozofii
uniwersyteckiej. Swoją edukację na poziomie

Andrzej Tomczak

(fot. w: Dorobek naukowy i dydaktyczny toruńskiego ośrodka archiwistyki, pod red. H. Robótki, Toruń 2011).

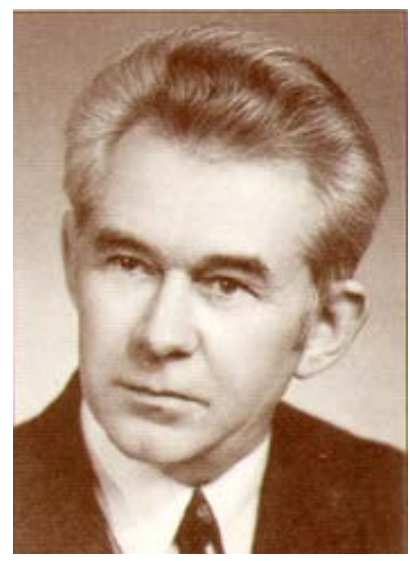

46 Były to następujące referaty: dr Lucyna Harc, E-Biblioteka Historyczna Uniwersytetu Wroctawskiego. Pomyst na reedycję i upowszechnienie ślaskich starodruków; dr Bar- 
szkoły powszechnej i gimnazjum ukończył w Łodzi, tam również rozpoczął naukę w Liceum Humanistycznym A. Zimowskiego, którą przerwał wybuch II wojny światowej. Po włączeniu Łodzi do Rzeszy, przedostał się do Generalnej Guberni. W 1941 roku wstąpił do Związku Walki Zbrojnej. Rok później złożył maturę w warszawskim tajnym Liceum św. Stanisława. Po zakończeniu wojny rozpoczął studia historyczne najpierw w Łodzi, a od 1946 roku kontynuował je na Uniwersytecie Mikołaja Kopernika w Toruniu. W trakcie studiów Andrzej Tomczak zainteresował się archiwistyką, co zaowocowało praktykami archiwalnymi w Archiwum Głównym Akt Dawnych, pod opieką wybitnych archiwistów - Jadwigi Karwasińskiej i Adama Stebelskiego. W 1948 roku uzyskał magisterium z filozofii w zakresie historii, na podstawie pracy Walenty Dembinski, ostatni kanclerz Polski Jagiellońskiej, którą napisał pod kierunkiem profesora Ludwika Kolankowskiego. Po ukończeniu studiów nadal związany był z toruńską uczelnią, gdzie pracował jako młodszy asystent, a później asystent. Dwa lata po uzyskaniu tytułu magistra zdobył tytuł doktora nauk humanistycznych na podstawie dysertacji pt. Walenty Dembiński i jego ród, której promotorem był również pierwszy rektor UMK. Jeszcze w 1950 roku, z powodów politycznych, zmuszono Tomczaka do opuszczenia uczelni. Przez następne sześć lat związany był z Łodzią i tamtejszym Wojewódzkim Archiwum Państwowym, gdzie pracował na stanowisku archiwisty, później kustosza. W rok po przełomie październikowym 1956 r. Andrzej Tomczak wrócił na Uniwersytet Mikołaja Kopernika w Toruniu, gdzie objął stanowisko adiunkta w Katedrze Archiwistyki i Nauk Pomocniczych Historii. W 1964 roku uzyskał na Wydziale Humanistycznym UMK stopień doktora habilitowanego w zakresie historii nowożytnej i nauk pomocniczych historii na podstawie rozprawy Kancelaria biskupów wtoctawskich $w$ okresie ksiegi wpisów (XV-XVIII w.) oraz kolokwium habilitacyjnego. Rok później został docentem w Instytucie Historii UMK. Pod koniec lat sześćdziesiątych, dzięki staraniom profesora Tomczaka, Instytut Historii UMK, jako jedyny w Polsce, zmienił nazwę na Instytut Historii i Archiwistyki UMK, a w miejsce Katedry Archiwistyki i Nauk Pomocniczych Historii zostały utworzone dwa samodzielne zakłady - Archiwistyki (na którego czele stanął Andrzej Tomczak) i Nauk Pomocniczych Historii. Od 1973r. przez pięć kolejnych lat Andrzej Tomczak pełnił funkcję zastępcy dyrektora Instytutu, w jego kom-

bara Techmańska, dr Małgorzata Skotnicka, Czy muzeum musi być nudne? Multimedialne projekty muzealne; dr Mariusz Brodnicki, Od etyki w stronę budowania cybernetyki. 
petencjach był m.in. rozwój nauki i kierunku archiwistyki. Ponownie zajmował to stanowisko w latach 1981-1987. Dnia 4 kwietnia 1974 roku Andrzej Tomczak uzyskał na mocy uchwały Rady Państwa tytuł profesora nadzwyczajnego, a 19 lutego 1981 roku otrzymał tytuł profesora zwyczajnego.

Nie sposób wymienić w skrócie wszystkich naukowych i pozanaukowych osiągnięć profesora Tomczaka. W swojej pracy wniósł bardzo wiele w rozwój archiwistyki polskiej. Wykształcił liczne grono uczniów, których znaczna część na resztę życia związała się z archiwistyką, pracując zarówno w archiwach, jak i na uniwersytetach. Do chwili obecnej profesor Tomczak bierze czynny udział w życiu uniwersyteckim, jest członkiem Stowarzyszenia Archiwistów Polskich, Towarzystwa Naukowego w Toruniu oraz innych instytucji. Profesor Tomczak to przede wszystkim znakomity dydaktyk, który w swojej pracy zarażał studentów historii i archiwistyki zainteresowaniami. Do chwili obecnej jego wykłady dotyczące historii archiwów w Polsce oraz archiwów w regionie cieszą się wyjątkową popularnością ${ }^{47}$.

W 2012 roku obchodzono jubileusz 90. urodzin Andrzeja Tomczaka. Rozpoczęły się one na VI Powszechnym Zjeździe Archiwistów Polskich we

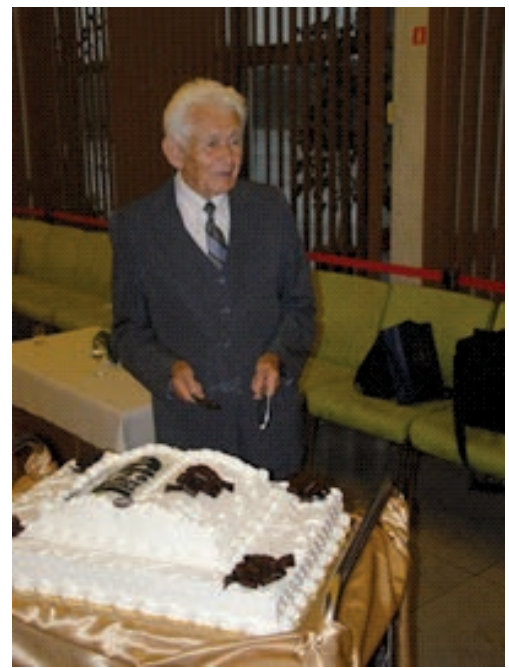

Andrzej Tomczak na jubileuszu 60-lecia toruńskiej archiwistyki (fot. K. Kopiński) Wrocławiu. Miało to miejsce we wrześniu tego roku.

Dnia 12 października 2012 roku obchody urodzin profesora odbyły się na Uniwersytecie Mikołaja Kopernika w Toruniu. Uroczystość zorganizowano w Sali Rady Wydziału Nauk Historycznych. Gospodarzem był dziekan WNH prof. Jacek Gzella, który powitał wszystkich gości, m.in. JM Rektora UMK prof. Andrzeja Tretyna, senatora Jana Wyrowińskiego oraz zgromadzonych przyjaciół i współpracowników Andrzeja Tomczaka. Łącznie na uroczystość przyjechało ponad dziewięćdziesięciu gości z całej Polski.

Pierwszy głos zabrał Jan Wyrowiński, który jako wicemarszałek Senatu RP

47 J. Tandecki, Profesor Andrzej Tomczak, cztowiek, uczony, nauczyciel. W osiemdziesiąta piątą rocznicę urodzin, „Archiwista Polski” nr 2 (46)/2007, s. 17-27. 
oraz Przewodniczący Rady Fundacji Generał Elżbiety Zawackiej, przekazał medal Senatu Rzeczypospolitej Polskiej dla profesora Tomczaka.

Następnie Janusz Tandecki przybliżył sylwetkę Jubilata: oprócz życiorysu, przybliżył również dokonania naukowe Andrzeja Tomczaka. Po tym wystąpieniu dziekan Jacek Gzella oddał głos JM Rektorowi; prelegent wyraził swoje ubolewanie, że późno poznał Andrzeja Tomczaka, a miało to miejsce w Klubie Profesora UMK. Rektor Tretyn pragnął uścisnąć dłoń Jubilata, który znał osobiście pierwszego rektora uniwersytetu, a następnie przekazał list gratulacyjny.

Następnie Dziekan przekazał głos prof. Jerzemu Wyrozumskiemu, sekretarzowi generalnemu PAU, który przeczytał list gratulacyjny od Polskiej Akademii Umiejętności, podpisany przez prezesa Andrzeja Białasa i sekretarza generalnego PAU.

Krzysztof Mikulski, jako były prezes Polskiego Towarzystwa Historycznego oraz przewodniczący Rady Archiwalnej, złożył gratulacje $\mathrm{w}$ imieniu nieobecnego prezesa PTH Jana Szymczaka.

Następny głos należał do przyjaciółki profesora Tomczaka - Elżbiety Wejmann, która złożyła serdeczne życzenia Jubilatowi oraz

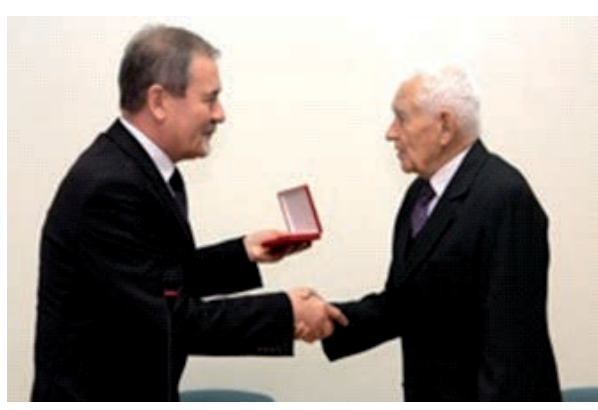

(fot. Andrzej Romański ) uraczyła przybyłych gości historią trudnej, ze względu na zawieruchę wojenną i czasy okupacji, przyjaźni z Andrzejem Tomczakiem.

Po tym wstąpieniu głos zabrali przedstawiciele władz archiwalnych. Kolejno listy gratulacyjne i życzenia przekazali: dyrektor AP w Łodzi - Piotr Zawilski, który odczytał również życzenia od prezesa Stowarzyszenia Archiwistów Polskich - Kazimierza Jaroszka, oraz Andrzej Biernat z NDAP, któryzłożył życzenia w imieniu Naczelnej Dyrekcji Archiwów Państwowych i przeczytał list gratulacyjny od Władysława Stępniaka - Naczelnego Dyrektora Archiwów Państwowych.

Wyjątkowe życzenia w postaci wiersza Jana Kasprowicza pt. Witajcie kochane góry, przeczytała Janina Huppental, reprezentantka toruńskich bibliofilów, do których grona od ponad 30 lat należy profesor Tomczak.

Dalsze życzenia i gratulacje złożyli przedstawiciele środowisk naukowych i akademickich: profesor Maria Koczerska z Uniwersytetu Warszawskiego oraz dr Hanna Krajewska z Archiwum Polskiej Akademii Nauk. 
Następnie głos zabrała była seminarzystka profesora Tomczaka, a obecna dyrektor AP w Toruniu - Beata Herdzin, która podziękowała za lata pracy naukowej oraz życzyła dalszych sukcesów. Do życzeń dołączył się dyrektor AP w Bydgoszczy - Eugeniusz Borodij.

Dalsze życzenia popłynęły z Uniwersytetu Marii Curie-Skłodowskiej w Lublinie; złożyli je prof. Krzysztof Skupieński oraz prof. Janusz Łosowski; kolejne wyrazy pamięci zostały odczytane przez prof. Irenę Mamczak-Gadkowską z Uniwersytetu Adama Mickiewicza w Poznaniu. Wielu lat w zdrowiu oraz dalszej pracy naukowej życzyli Jubilatowi: Henryk Krystek, dyrektor AP w Poznaniu, Przemysław Wojciechowski z redakcji „Rocznika Toruńskiego" oraz Hubert Wajs - dyrektor Archiwum Głównego Akt Dawnych.

Wielką niespodziankę sprawiła Jubilatowi wizyta emerytowanego kierownika zakładu archiwistyki w Centralnym Archiwum Wojskowym - Bolesława Woszczyńskiego, który do serdecznych gratulacji dołożył życzenie następnego jubileuszu urodzin.

$\mathrm{Na}$ końcu życzenia złożyli najbliżsi współpracownicy profesora Tomczaka. Zaczął zastępca dyrektora Instytutu Historii i Archiwistyki UMK - Jarosław Kłaczkow. Następnie głos zabrała prof. Wiesława Kwiatkowska z Zakładu Archiwistyki, która oprócz gratulacji od pracowników przeczytała życzenia nadesłane pocztą z Polski i zagranicy. Prof. Halina Robótka przekazała życzenia od pracowników i doktorantów z Zakładu Zarządzania Dokumentacją i Informacji Archiwalnej.

Dziekan Jacek Gzella podziękował za liczne przybycie i życzenia, by następnie przekazać głos Andrzejowi Tomczakowi. Jubilat podziękował za sympatię, uznanie oraz zaskakująco liczne przybycie. Wyrazy wdzięczności skierował do osób, które go wszystkiego nauczyły, przez lata służyły pomocą, a których niestety już wśród nas nie ma.

Na koniec prof. Waldemar Chorążyczewski zaprezentował księgę pamiątkową, dedykowaną Andrzejowi Tomczakowi, która została wydana przez SAP i NDAP. Silva rerum opera hisorica, diplomatica et archivistica continens, Andreae Tomczak dedicata z założenia miała być zbiorem artykułów naukowych, które dotyczą spraw ważnych dla profesora Tomczaka, zarówno ze względów życiowych, jak i zainteresowań naukowych.

Magdalena Niedźwiedzka Uniwersytet Mikołaja Kopernika w Toruniu 